\title{
Optimization of the associative growth of novel yoghurt cultures in the production of biomass, $\beta$-galactosidase and lactic acid using response surface methodology
}

\author{
Canan Tari $^{\mathrm{a}, *}$, Fatma Isık Ustok ${ }^{\mathrm{b}}$, Sebnem Harsa ${ }^{\mathrm{a}}$

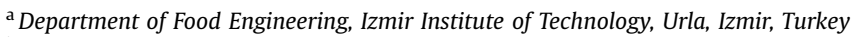 \\ ${ }^{\mathrm{b}}$ Biotechnology and Bioengineering Programme, Izmir Institute of Technology, Izmir, Turkey
}

\section{A R T I C L E I N F O}

\section{Article history:}

Received 24 March 2008

Received in revised form

21 October 2008

Accepted 31 October 2008

\begin{abstract}
A B S T R A C T
The associative growth of Streptococcus thermophilus 95/2 (St 95/2) and Lactobacillus delbrueckii ssp. bulgaricus 77 ( Lb 77) isolated from the Toros mountain region of Turkey was investigated with respect to lactic acid, biomass and $\beta$-galactosidase enzyme production using response surface methodology (RSM). The ratio (St 95/2:Lb 77) of the strains and media formulation had significant effect on all responses $(p<0.001)$. The predicted enzyme activity $\left(2.14 \mathrm{U} \mathrm{mL}^{-1}\right)$, lactic acid $\left(22.50 \mathrm{~g} \mathrm{~L}^{-1}\right)$ and biomass $\left(7.11 \mathrm{~g} \mathrm{~L}^{-1}\right)$ production at optimum conditions were very close to the actual experimental values $\left(2.14 \mathrm{UmL}^{-1}\right.$, $22.94 \mathrm{~g} \mathrm{~L}^{-1}$ and $7.86 \mathrm{~g} \mathrm{~L}^{-1}$, respectively). The optimum conditions were to use these cultures in a ratio of $1.66: 1.62$ (St 95/2:Lb 77) in a medium containing whey (5\%), corn steep liquor (4\%), potassium phosphate (2\%) and peptone $(2 \%)$ at $43{ }^{\circ} \mathrm{C}$ for $8 \mathrm{~h}$. The associative growth provided $6.4 \%$ and $39 \%$ more $\beta$-galactosidase activity and $8.73 \%$ and $44 \%$ more lactic acid compared with the results obtained using pure St 95/2 and Lb 77 strains, respectively.
\end{abstract}

(c) 2008 Elsevier Ltd. All rights reserved.

\section{Introduction}

Yoghurt, a major food product with an increasing consumption rate due to its health promoting properties, is produced by the action of yoghurt bacteria (Lactobacillus delbrueckii ssp. bulgaricus and Streptococcus thermophilus) and their metabolites (Kristo et al., 2003). The compounds that provide the typical flavour in yoghurt are lactic acid and volatile organic aroma compounds such as acetaldehyde, diacetyl and acetone (Beshkova et al., 1998). Lactic acid is a valuable product that has several applications in food, chemical and pharmaceutical industries. Its current worldwide production is estimated to be around $120000 \mathrm{MT} \mathrm{y}^{-1}$, growth being due to its recent potential as major feedstock, derived from renewable carbohydrates by sustainable technologies, to make plastics, fibers, solvents and oxygenated chemicals. This increase has been mainly attributed to the development of new technologies in the fields of separation and purification (Datta and Henry, 2006).

Lactase, i.e., $\beta$-galactosidase (E.C. 3.2.1.23), an enzyme produced by lactic acid bacteria (LAB) that hydrolyzes lactose (an abundant disaccharide found in milk) to glucose and galactose, has potential importance in the dairy industry (El Demerdash et al., 2006; Nancip et al., 1999; Vasiljevic and Jelen, 2001, 2002). The nutritional value

\footnotetext{
* Corresponding author. Tel.: +90 232 7506316; fax: +90 2327506196 .

E-mail address: canantari@iyte.edu.tr (C. Tari).
}

of lactose is limited due to the fact that a large proportion (50\%) of world's inhabitants lacks this enzyme and cannot utilize lactose, thereby developing lactose maldigestion or intolerance (Greenberg and Mahoney, 1982; Somkouti et al., 1996; Vasiljevic and Jelen, 2002). This, however, creates a potential market for the application of $\beta$-galactosidase.

Although $\beta$-galactosidase has been found in several biological systems, yeast, molds and bacteria are the main sources for commercial purposes (Vasiljevic and Jelen, 2001). In recent years, lactic acid bacteria have gained more importance due to generally regarded as safe (GRAS) status and much research has been conducted on their use (Vasiljevic and Jelen, 2001, 2002, 2003). Among lactic acid bacteria, L. delbrueckii ssp. bulgaricus and $S$. thermophilus are the highest $\beta$-galactosidase producers (Greenberg and Mahoney, 1982; Shah and Jelen, 1991; Vasiljevic and Jelen, 2001). The $\beta$-galactosidase of these cultures has been characterized, showing greater stability at high temperatures $\left(50^{\circ} \mathrm{C}\right)$ than the $\beta$-galactosidase obtained from Kluyveromyces lactis (Greenberg and Mahoney, 1982; Kreft and Jelen, 2000). At these conditions (neutral pH and high temperatures), hydrolysis of lactose can be achieved rapidly without growth of undesirable microorganisms (Greenberg and Mahoney, 1982; Vasiljevic and Jelen, 2001). However, LAB cultures are not as high biomass producers as are yeasts, and would not produce lactase at high enough concentrations to be commercially viable as an enzyme producer (Gekas and Lopez-Leiva, 1985). 
In this particular study, a strategy to overcome this problem was to use the advantage of their associative growth properties in the increase of the enzyme yield. The growth between $S$. thermophilus and $L$. delbrueckii ssp. bulgaricus is defined as associative since each organism can grow separately and when grown together provides compounds which benefit the other (Tamime and Robinson, 1999). This strategy would not only enhance the product yield, but also provide a diverse range of metabolite production that could be of interest for further research. Most studies described in literature investigated the effect of symbiotic relations on rheological and microbiological properties of dairy products only (Sodini et al., 2005). Furthermore, most of the studies on $\beta$-galactosidase production were carried using single strains (Greenberg and Mahoney, 1982; Vasiljevic and Jelen, 2001, 2002, 2003). The originality of this study, however, lies in investigating the impact of a mixed culture on $\beta$-galactosidase, lactic acid and biomass production.

With this perspective, 136 LAB cultures isolated from Toros mountain region of Turkey were screened and, from these isolates, S. thermophilus 95/2 (coded as St 95/2) and L. delbrueckii ssp. bulgaricus 77 (coded as Lb 77) were determined as potential lactic acid and $\beta$-galactosidase enzyme producers (unpublished data). The aim of this study was the optimization of the fermentation conditions of pure and mixed cultures of Lb 77 and St 95/2 using response surface methodology with respect to biomass formation, lactic acid and $\beta$-galactosidase enzyme production. The optimization studies were carried out in shake flasks, and data obtained were adapted to bioreactor scale under controlled environment.

\section{Material and methods}

\subsection{Microorganisms and culture propagation}

L. delbrueckii ssp. bulgaricus 77 and S. thermophilus 95/2 were isolated from traditional yoghurt samples of Toros mountain region of Turkey. Phenotypic and genotypic characterizations of the cultures were performed by the Molecular Food Biotechnology research group at Izmir Institute of Technology (Erkuş et al., 2006). Stock cultures of these strains were prepared by mixing $0.5 \mathrm{~mL}$ of activated culture with $0.5 \mathrm{~mL}$ of glycerol-broth solution (40\%) and stored at $-80^{\circ} \mathrm{C}$ in sterile cryovials. Culture propagation was carried out by transferring $10 \mu \mathrm{L}$ of the stock culture of St 95/2 and Lb 77 into $10 \mathrm{~mL}$ of sterile M17 and MRS broth, respectively, and incubating overnight at $43^{\circ} \mathrm{C}$.

\subsection{Fermentation}

Fermentations were carried out both in shake flasks and bioreactor. Optimization studies were performed in $250 \mathrm{~mL}$ Erlenmeyer flasks containing $100 \mathrm{~mL}$ of sterilized broths of skim milk (8-16\%, w/v) for Lb 77 and $100 \mathrm{~mL}$ fermentation medium containing whey $(0-5 \%, w / v)$, corn step liquor (CSL) (Sigma C 4648, Sigma-Aldrich Inc. St Louis, MO, USA) (0-5\%, w/v), peptone $(2 \%, \mathrm{w} / \mathrm{v})$ and potassium phosphate $(2 \%, \mathrm{w} / \mathrm{v})$ for St $95 / 2$. Media used during these optimization studies were chosen according to the results of preliminary screening experiments based on medium and culture selection (unpublished work). These media were inoculated with predefined inoculum ranges of propagated culture $\left(2-4 \%, \mathrm{v} / \mathrm{v}\right.$ which were $1.20 \times 10^{8}-2.40 \times 10^{8} \mathrm{cfu} \mathrm{mL}^{-1}$ for Lb 77 and $1.40 \times 10^{8}-2.80 \times 10^{8} \mathrm{cfu} \mathrm{mL}^{-1}$ for St 95/2) and incubated at predefined temperatures $\left(35-43^{\circ} \mathrm{C}\right.$ for Lb 77 and $35-45^{\circ} \mathrm{C}$ for St $95 / 2$ ) for $8 \mathrm{~h}$ without agitation as described in the experimental design Section 2.8 (Tables 1 and 2).

During the fermentation, $\mathrm{pH}$ in shake flasks could not be controlled due to the risk of contamination and the high number of runs given by the experimental design. In shake flasks, the initial $\mathrm{pH}$ of the fermentation medium was $6.5-6.8$ for Lb 77 and 7.0-7.6 for St 95/2 (depending on the medium formulation).

The associative relationship of St 95/2 and Lb 77 was determined according to the results obtained from the optimization studies described above. Two types of optimized media formulations were used in this fermentation. Medium A was prepared by reconstituting $8 \mathrm{~g}$ skim milk powder (obtained from spray-dried pasteurized milk, Pınar Süt Inc. Izmir, Turkey) in $100 \mathrm{~mL}$ deionized water and Medium B was prepared by reconstituting sweet whey powder ( $5 \mathrm{~g}$; obtained from spray-dried sweet whey: Pınar Süt Inc.), CSL ( $4 \mathrm{~g})$, potassium phosphate $(2 \mathrm{~g})$ and peptone $(2 \mathrm{~g})$ in $100 \mathrm{~mL}$ deionized water. These media were inoculated with activated cultures (Lb 77 and St 95/2) as described in experimental design (Table 3). The initial $\mathrm{pH}$ for Medium A was 6.78 and for Medium B was pH 7.2.

To investigate the effect of $\mathrm{pH}$ control on $\beta$-galactosidase activity and lactic acid production, bioreactor studies $(2.5 \mathrm{~L})$ were performed at optimized conditions with and without $\mathrm{pH}$ control using an Infors-Minifors Bioreactor (Infors HT, Bottmingen, Switzerland) $(5 \mathrm{~L})$ for pure and mixed cultures.

\subsection{Disruption of microbial biomass}

Since $\beta$-galactosidase from both $S$. thermophilus and $L$. delbrueckii ssp. bulgaricus is an intracellular enzyme, lysozyme enzyme treatment was used for enzyme extraction. For the extraction procedure, $10 \mathrm{~mL}$ of fermentation broth was harvested by centrifugation at $2800 \times \mathrm{g}$ for $15 \mathrm{~min}$ at $4{ }^{\circ} \mathrm{C}$ followed by washing the pellet with $10 \mathrm{~mL}$ of $0.05 \mathrm{~m}$ sodium phosphate buffer $(\mathrm{pH} 7)$ and centrifuging at $2800 \times \mathrm{g}$ for another $15 \mathrm{~min}$. After the washing step, the pellet was resuspended in $4.5 \mathrm{~mL}$ of the same buffer followed by vigorous vortexing. Afterwards, $100 \mathrm{mg}$ of lysozyme (Sigma L 6876, Sigma-Aldrich Inc. St Louis, MO, USA) was added to this solution and incubated at $37^{\circ} \mathrm{C}$ for $15 \mathrm{~min}$. After this, $0.5 \mathrm{~mL}$ of $4 \mathrm{M} \mathrm{NaCl}$ solution was added and incubated further at $37^{\circ} \mathrm{C}$ for another $50 \mathrm{~min}$ followed by centrifugation at $2800 \times \mathrm{g}$ for $15 \mathrm{~min}$. Following centrifugation, the supernatant was used for the enzyme assay.

\subsection{Enzyme assay}

The activity of $\beta$-galactosidase was assayed according to the procedure described in the Food chemical codex (National Academy of Sciences, 1996). The chromogenic substrate o-nitrophenol- $\beta$ D-galactopyranoside (ONPG, Sigma N 1127, Sigma-Aldrich Inc.) $\left(8.3 \times 10^{-3} \mathrm{M}\right)$ dissolved in $0.05 \mathrm{~m}$ sodium phosphate buffer $(\mathrm{pH} 7.0)$ was used. The amount of substrate and enzymes used were $2 \mathrm{~mL}$ and $0.5 \mathrm{~mL}$, respectively. At time zero, $0.5 \mathrm{~mL}$ of enzyme solution was added to the ONPG solution and incubated for $15 \mathrm{~min}$. The assay was stopped by the addition of $0.5 \mathrm{~mL} 10 \%$ sodium carbonate, and the absorbance was determined at $420 \mathrm{~nm}$. One unit was defined as the quantity of enzyme that would liberate $1 \mathrm{~mm}$ of onitrophenol from ONPG per minute under the assay conditions. Units were calculated using the following equation:

$$
\begin{aligned}
\text { Unit } \mathrm{mL}^{-1}= & A \times \text { dilution factor } / \\
& (\epsilon \times \text { time } \times \text { enzyme solution })
\end{aligned}
$$

where $A$ was the absorbance at $420 \mathrm{~nm}$, dilution factor was the fold dilution of the enzyme solution, enzyme solution was the amount of enzyme $(\mathrm{mL})$ undergoing the reaction, $\epsilon$ was the extinction coefficient (determined from the o-nitrophenol standard curve) and time was the incubation time (15 min). 
Table 1

Optimization of Lb77 culture conditions for production of $\beta$-galactosidase activity, biomass and lactic acid using a face-centered central composite design matrix.

\begin{tabular}{|c|c|c|c|c|c|c|}
\hline Run & Temperature $\left({ }^{\circ} \mathrm{C}\right)$ & Inoculum $\left(\mathrm{cfu} \mathrm{mL} \mathrm{m}^{-1}\right)$ & Skim milk (\%) & Activity $\left(\mathrm{U} \mathrm{mL}^{-1}\right)$ & Biomass $\left(\mathrm{g} \mathrm{L}^{-1}\right)$ & Lactic acid $\left(\mathrm{g} \mathrm{L}^{-1}\right)$ \\
\hline$\overline{1^{a}}$ & 39 & $1.80 \times 10^{8}$ & 12 & 1.186 & 8.35 & 7.69 \\
\hline 2 & 43 & $1.80 \times 10^{8}$ & 12 & 1.258 & 9.35 & 10.45 \\
\hline $3^{a}$ & 39 & $1.80 \times 10^{8}$ & 12 & 1.179 & 9.15 & 7.62 \\
\hline 4 & 35 & $2.40 \times 10^{8}$ & 16 & 0.18 & 3.35 & 1.98 \\
\hline 5 & 35 & $2.40 \times 10^{8}$ & 8 & 0.239 & 4.86 & 6.06 \\
\hline 6 & 35 & $1.20 \times 10^{8}$ & 8 & 0.121 & 3.15 & 5.41 \\
\hline $7^{\mathrm{a}}$ & 39 & $1.80 \times 10^{8}$ & 12 & 1.185 & 8.35 & 7.65 \\
\hline $8^{a}$ & 39 & $1.80 \times 10^{8}$ & 12 & 1.191 & 8.18 & 7.63 \\
\hline 9 & 39 & $1.80 \times 10^{8}$ & 16 & 0.957 & 6.95 & 4.21 \\
\hline 10 & 35 & $1.20 \times 10^{8}$ & 16 & 0.492 & 4.35 & 1.54 \\
\hline 11 & 43 & $1.20 \times 10^{8}$ & 8 & 0.814 & 5.27 & 9.27 \\
\hline 12 & 43 & $2.40 \times 10^{8}$ & 16 & 0.873 & 5.8 & 7.58 \\
\hline 13 & 43 & $1.20 \times 10^{8}$ & 16 & 0.457 & 4.51 & 7.99 \\
\hline 14 & 43 & $2.40 \times 10^{8}$ & 8 & 1.341 & 9.45 & 14.44 \\
\hline 15 & 39 & $1.80 \times 10^{8}$ & 8 & 0.997 & 7.85 & 8.14 \\
\hline $16^{\mathrm{a}}$ & 39 & $1.80 \times 10^{8}$ & 12 & 1.191 & 9.16 & 7.58 \\
\hline $17^{\mathrm{a}}$ & 39 & $1.80 \times 10^{8}$ & 12 & 1.183 & 8.15 & 7.61 \\
\hline 18 & 35 & $1.80 \times 10^{8}$ & 12 & 0.549 & 4.75 & 2.19 \\
\hline 19 & 39 & $2.40 \times 10^{8}$ & 12 & 1.02 & 7.65 & 8.42 \\
\hline 20 & 39 & $1.20 \times 10^{8}$ & 12 & 0.987 & 6.85 & 5.97 \\
\hline
\end{tabular}

${ }^{\mathrm{a}}$ The average and the standard deviation among the repeated experiments performed at all center points were $1.186 \pm 0.005 \mathrm{U} \mathrm{mL}^{-1}, 8.56 \pm 0.47 \mathrm{~g} \mathrm{~L}^{-1}$, and $7.63 \pm 0.037 \mathrm{~g} \mathrm{~L}^{-1}$ for activity ( $\beta$-galactosidase activity), biomass and lactic acid, respectively.

\subsection{Biomass determination}

Due to whey or milk protein precipitation at low $\mathrm{pH}$ values, biomass data could not be determined adequately. To minimize the contribution of protein precipitates to the biomass weight, sterile media (sterilized at $113^{\circ} \mathrm{C}$ for $10 \mathrm{~min}$ ) used during the fermentation were prepared and their $\mathrm{pH}$ were adjusted to the final $\mathrm{pH}$ obtained at the end of fermentation. The amount of protein precipitates was determined by centrifugation (at $2800 \times \mathrm{g}$ for $15 \mathrm{~min}$ ) and drying the pellet at $43^{\circ} \mathrm{C}$ until constant weight was reached. The biomass, including the precipitate at the end of each fermentation, was centrifuged and dried to constant weight. The biomass $\left(\mathrm{g} \mathrm{L}^{-1}\right)$ was determined by subtracting the amount of protein precipitates (determined from sterile medium) from dried pellet (biomass including the precipitate) obtained at the end of fermentation. This approach provided an approximation of the biomass produced.

\subsection{Lactose and lactic acid determination}

Lactose and lactic acid determination were performed by using Perkin Elmer HPLC system (Perkin Elmer, Boston, MA, USA) equipped with a pump (PE Series 200), refractive index detector (PE

Table 2

Optimization of St 95/2 culture conditions for production of $\beta$-galactosidase activity, biomass and lactic acid using a face-centered central composite design matrix.

\begin{tabular}{|c|c|c|c|c|c|c|c|}
\hline Run & Temperature ${ }^{\circ} \mathrm{C}$ & Inoculum (cfu mL $\left.{ }^{-1}\right)$ & Whey (\%) & $\mathrm{CSL}^{\mathrm{b}}(\%)$ & Activity $\left(\mathrm{U} \mathrm{mL}^{-1}\right)$ & Biomass $\left(\mathrm{g} \mathrm{L}^{-1}\right)$ & Lactic acid $\left(\mathrm{g} \mathrm{L}^{-1}\right)$ \\
\hline$\overline{1^{a}}$ & 40 & $2.10 \times 10^{8}$ & 2.5 & 2.5 & 1.796 & 6.75 & 13.45 \\
\hline $2^{\mathrm{a}}$ & 40 & $2.10 \times 10^{8}$ & 2.5 & 2.5 & 1.805 & 6.80 & 13.40 \\
\hline 3 & 35 & $2.10 \times 10^{8}$ & 2.5 & 2.5 & 0.485 & 4.15 & 9.90 \\
\hline 4 & 45 & $1.40 \times 10^{8}$ & 5 & 5 & 0.755 & 8.50 & 19.92 \\
\hline $5^{a}$ & 40 & $2.10 \times 10^{8}$ & 2.5 & 2.5 & 1.792 & 6.76 & 13.28 \\
\hline 6 & 45 & $1.40 \times 10^{8}$ & 5 & 0 & 0.014 & 3.55 & 1.49 \\
\hline 7 & 35 & $2.80 \times 10^{8}$ & 0 & 0 & 0.091 & 1.75 & 0 \\
\hline $8^{a}$ & 40 & $2.10 \times 10^{8}$ & 2.5 & 2.5 & 1.764 & 6.87 & 13.36 \\
\hline 9 & 40 & $2.10 \times 10^{8}$ & 5 & 2.5 & 0.964 & 7.75 & 16.69 \\
\hline 10 & 40 & $2.10 \times 10^{8}$ & 2.5 & 5 & 0.336 & 7.35 & 13.46 \\
\hline 11 & 35 & $1.40 \times 10^{8}$ & 5 & 0 & 0.011 & 2.95 & 1.05 \\
\hline 12 & 35 & $2.80 \times 10^{8}$ & 5 & 0 & 0.061 & 3.85 & 2.54 \\
\hline 13 & 45 & $2.80 \times 10^{8}$ & 5 & 5 & 1.196 & 9.65 & 22.75 \\
\hline 14 & 40 & $2.10 \times 10^{8}$ & 0 & 2.5 & 0.196 & 2.40 & 9.56 \\
\hline $15^{a}$ & 40 & $2.10 \times 10^{8}$ & 2.5 & 2.5 & 1.794 & 6.85 & 13.48 \\
\hline 16 & 45 & $1.40 \times 10^{8}$ & 0 & 0 & 0.056 & 1.70 & 0 \\
\hline 17 & 35 & $2.80 \times 10^{8}$ & 5 & 5 & 0.628 & 8.17 & 10.62 \\
\hline 18 & 45 & $2.80 \times 10^{8}$ & 0 & 0 & 0.062 & 1.40 & 0 \\
\hline 19 & 45 & $2.10 \times 10^{8}$ & 2.5 & 2.5 & 1.133 & 5.65 & 11.75 \\
\hline $20^{a}$ & 40 & $2.10 \times 10^{8}$ & 2.5 & 2.5 & 1.828 & 6.78 & 13.45 \\
\hline 21 & 45 & $1.40 \times 10^{8}$ & 0 & 5 & 0.17 & 3.80 & 11.78 \\
\hline 22 & 40 & $1.40 \times 10^{8}$ & 2.5 & 2.5 & 1.160 & 4.35 & 7.86 \\
\hline 23 & 35 & $1.40 \times 10^{8}$ & 5 & 5 & 0.316 & 5.50 & 8.38 \\
\hline 24 & 35 & $1.40 \times 10^{8}$ & 0 & 5 & 0.097 & 2.85 & 7.81 \\
\hline 25 & 35 & $1.40 \times 10^{8}$ & 0 & 0 & 0.062 & 1.05 & 0 \\
\hline 26 & 45 & $2.80 \times 10^{8}$ & 0 & 5 & 0.473 & 5.35 & 12.14 \\
\hline 27 & 40 & $2.80 \times 10^{8}$ & 2.5 & 2.5 & 2.027 & 7.95 & 14.28 \\
\hline 28 & 40 & $2.10 \times 10^{8}$ & 2.5 & 0 & 0.029 & 4.95 & 2.85 \\
\hline 29 & 35 & $2.80 \times 10^{8}$ & 0 & 5 & 0.206 & 3.20 & 10.54 \\
\hline 30 & 45 & $2.80 \times 10^{8}$ & 5 & 0 & 0.022 & 4.72 & 3.71 \\
\hline
\end{tabular}

a The average and the standard deviation among the repeated experiments performed at all center points were $1.796 \pm 0.021 \mathrm{UmL}^{-1}, 6.80 \pm 0.048 \mathrm{~g} \mathrm{~L}^{-1}$, and $13.41 \pm 0.076 \mathrm{~g} \mathrm{~L}^{-1}$ for activity ( $\beta$-galactosidase activity), biomass and lactic acid, respectively.

b CSL: corn steep liquor. 
Table 3

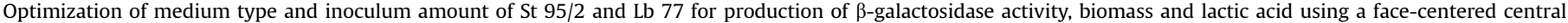
composite design matrix.

\begin{tabular}{|c|c|c|c|c|c|c|}
\hline Run & St $95 / 2\left(\right.$ cfu $\left.L^{-1}\right)$ & Lb $77\left({\left.\text { cfu } \mathrm{mL}^{-1}\right)}^{-1}\right.$ & Medium & Activity $\left(\mathrm{UmL}^{-1}\right)$ & Biomass $\left(\mathrm{g} \mathrm{L}^{-1}\right)$ & Lactic acid $\left(\mathrm{g} \mathrm{L}^{-1}\right)$ \\
\hline$\overline{1^{a}}$ & $1.24 \times 10^{8}$ & $1.08 \times 10^{8}$ & A & 0.748 & 8.56 & 8.18 \\
\hline $2^{\mathrm{b}}$ & $1.24 \times 10^{8}$ & $1.08 \times 10^{8}$ & B & 1.748 & 6.75 & 21.33 \\
\hline $3^{b}$ & $1.24 \times 10^{8}$ & $1.08 \times 10^{8}$ & B & 1.723 & 6.87 & 21.35 \\
\hline $4^{a}$ & $1.24 \times 10^{8}$ & $1.08 \times 10^{8}$ & A & 0.754 & 8.78 & 8.16 \\
\hline $5^{a}$ & $1.24 \times 10^{8}$ & $1.08 \times 10^{8}$ & A & 0.758 & 9.02 & 8.17 \\
\hline 6 & $1.86 \times 10^{8}$ & $1.08 \times 10^{8}$ & A & 0.806 & 10.12 & 9.85 \\
\hline $7^{\mathrm{a}}$ & $1.24 \times 10^{8}$ & $1.08 \times 10^{8}$ & A & 0.752 & 8.93 & 8.18 \\
\hline 8 & $1.86 \times 10^{8}$ & $1.62 \times 10^{8}$ & B & 2.058 & 7.18 & 18.43 \\
\hline 9 & $0.62 \times 10^{8}$ & $1.08 \times 10^{8}$ & A & 0.538 & 6.92 & 5.88 \\
\hline 10 & $1.24 \times 10^{8}$ & $1.62 \times 10^{8}$ & B & 2.144 & 6.45 & 24.86 \\
\hline $11^{\mathrm{a}}$ & $1.24 \times 10^{8}$ & $1.08 \times 10^{8}$ & A & 0.754 & 8.97 & 8.15 \\
\hline 12 & $0.62 \times 10^{8}$ & $1.62 \times 10^{8}$ & A & 0.693 & 7.75 & 6.02 \\
\hline 13 & $0.62 \times 10^{8}$ & $0.54 \times 10^{8}$ & A & 0.655 & 6.90 & 7.07 \\
\hline 14 & $0.62 \times 10^{8}$ & $1.62 \times 10^{8}$ & B & 1.531 & 4.65 & 20.45 \\
\hline 15 & $0.62 \times 10^{8}$ & $1.08 \times 10^{8}$ & B & 1.235 & 4.21 & 18.64 \\
\hline 16 & $1.86 \times 10^{8}$ & $1.62 \times 10^{8}$ & A & 1.013 & 10.25 & 11.31 \\
\hline 17 & $1.86 \times 10^{8}$ & $1.08 \times 10^{8}$ & B & 1.739 & 5.97 & 22.31 \\
\hline 18 & $1.24 \times 10^{8}$ & $0.54 \times 10^{8}$ & B & 1.327 & 5.10 & 19.16 \\
\hline $19^{\mathrm{b}}$ & $1.24 \times 10^{8}$ & $1.08 \times 10^{8}$ & B & 1.740 & 6.23 & 21.30 \\
\hline 20 & $1.24 \times 10^{8}$ & $1.62 \times 10^{8}$ & A & 0.734 & 10.18 & 8.75 \\
\hline 21 & $1.86 \times 10^{8}$ & $0.54 \times 10^{8}$ & A & 0.544 & 7.15 & 5.17 \\
\hline 22 & $1.24 \times 10^{8}$ & $0.54 \times 10^{8}$ & A & 0.495 & 6.85 & 5.29 \\
\hline $23^{\mathrm{b}}$ & $1.24 \times 10^{8}$ & $1.08 \times 10^{8}$ & B & 1.734 & 6.23 & 21.39 \\
\hline 24 & $0.62 \times 10^{8}$ & $0.54 \times 10^{8}$ & B & 1.124 & 4.87 & 14.76 \\
\hline 25 & $1.86 \times 10^{8}$ & $0.54 \times 10^{8}$ & B & 1.256 & 5.26 & 16.70 \\
\hline $26^{\mathrm{b}}$ & $1.24 \times 10^{8}$ & $1.08 \times 10^{8}$ & B & 1.637 & 6.20 & 21.33 \\
\hline
\end{tabular}

a The average and the standard deviation among the repeated experiments performed at all center points using Medium $\mathrm{A}$ were $0.753 \pm 0.004 \mathrm{U} \mathrm{mL}^{-1}, 8.85 \pm 0.186 \mathrm{~g} \mathrm{~L}^{-1}$ and $8.61 \pm 0.013 \mathrm{~g} \mathrm{~L}^{-1}$ for activity ( $\beta$-galactosidase activity), biomass and lactic acid, respectively.

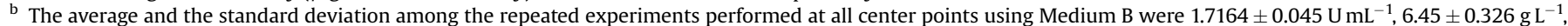
and $21.34 \pm 0.033 \mathrm{~g} \mathrm{~L}^{-1}$ for activity ( $\beta$-galactosidase activity), biomass and lactic acid, respectively.

Series 200) and interface (PE Series 900). Samples (20 $\mu \mathrm{L})$ were injected through the injection port. The separation was performed with an Aminex HPX-87H ion exclusion column $(300 \times 7.8 \mathrm{~mm})$ (Bio-Rad Laboratories, Hercules, CA, USA). The column was heated at $45^{\circ} \mathrm{C}$ in column oven (Metatherm, Lake Forest, CA, USA). The conditions applied were: $5 \mathrm{~mm} \mathrm{H}_{2} \mathrm{SO}_{4}$ as mobile phase at a flow rate of $0.6 \mathrm{~mL} \mathrm{~min}^{-1}$. Data acquisition and peak processing were performed with Total Chrom Workstation ver. 6.2.1 software (Perkin Elmer). Peak identification was based on retention times and peak quantification was based on the external standard method. In this method, the reference standards were chosen to be the same as the solutes in the sample and given to the system separately. Initial and residual lactose amounts were recorded and used in calculations of yield coefficients.

\subsection{Microbiological analysis}

To investigate the effect of associative growth on final cell counts, microorganisms were enumerated using differential media (Hekmat and McMahon, 1997; Shah, 2000; Van de Casteele et al., 2006; Yüceer et al., 2001). L. delbrueckii ssp. bulgaricus was enumerated on MRS agar ( $\mathrm{pH} 5.4$ ) after anaerobic incubation at $43^{\circ} \mathrm{C}$ for $48 \mathrm{~h}$ (at $\mathrm{pH} 5.4$ no growth of $S$. thermophilus was observed). S. thermophilus was counted on M17 agar after incubation at $43^{\circ} \mathrm{C}$ for $48 \mathrm{~h}$.

\subsection{Experimental design and statistical analysis}

Three different optimization studies were performed using the statistical software called Design Expert 7.0 trial version (Stat-Ease Inc. Minneapolis, MN, USA). In the first optimization, effects of independent variables including temperature $\left(X_{1}\right)$, inoculum $\left(X_{2}\right)$ and skim milk concentration $\left(X_{3}\right)$ were investigated on the responses of lactic acid, biomass and $\beta$-galactosidase activity using Lb 77. A face-centered composite design (CCD) with three factors was used (Table 1 ). In the second optimization, effects of independent variables temperature $\left(X_{1}\right)$, inoculum $\left(X_{2}\right)$, whey concentration $\left(X_{3}\right)$ and corn steep liquor (CSL) $\left(X_{4}\right)$ were investigated on the responses of lactic acid, biomass and $\beta$-galactosidase activity using St 95/2. A face-CCD with four factors was used (Table 2).

Based on the results obtained from the optimization studies described above, a third optimization study was performed to investigate the associative relationship between Lb 77 and St 95/2. Effects of independent variables such as inoculum ratio of St 95/2 $\left(X_{1}\right)$, inoculum ratio of $\mathrm{Lb} 77\left(X_{2}\right)$ and media formulation $\left(X_{3}\right)$ on the responses of lactic acid, biomass and $\beta$-galactosidase activity were investigated (Table 3 ).

In all optimization studies, analysis of data and generation of response surface plots were achieved with the statistical software Design Expert (trial version). The response variables in three sets of experiments were lactic acid, biomass and $\beta$-galactosidase activity. A second-order polynomial equation including the interactions was fitted to the response data by multiple regression procedure, after running the experiments and measuring the response variables:

$Y=\beta_{0}+\sum_{i=1}^{k} \beta_{\mathrm{i}} X_{\mathrm{i}}+\sum_{i=1}^{k} \beta_{\mathrm{ii}} X_{\mathrm{i}}^{2}+\sum_{i} \sum_{j} \beta_{\mathrm{ij}} X_{\mathrm{i}} X_{\mathrm{j}}+\epsilon$

where $Y$ is the predicted response, $k$ is the number of factor variables, $\beta_{0}$ is the model constant, $\beta_{\mathrm{i}}$ is linear coefficient, $X_{\mathrm{i}}$ and $X_{\mathrm{j}}$ are independent variables in its coded form, $\beta_{\mathrm{ii}}$ is the quadratic coefficient, $\beta_{\mathrm{ij}}$ is the interaction coefficient and $\epsilon$ is the error factor. To code the actual experimental values of the factors in a range of $[-1+1]$, the following equation was used:

$x=$ actual

$$
-(\text { low level }+ \text { high level }) / 2] /(\text { high level }- \text { low level }) / 2
$$

The analysis of variance (ANOVA) tables were generated and the effect and regression coefficients of individual linear, quadratic and 
Table 4

$R^{2}$, Adjusted $R^{2}$ and Predicted $R^{2}$ values of optimization studies.

\begin{tabular}{|c|c|c|c|c|c|c|c|c|c|}
\hline \multirow[t]{2}{*}{ Parameter } & \multicolumn{3}{|l|}{ Activity } & \multicolumn{3}{|l|}{ Lactic Acid } & \multicolumn{3}{|l|}{ Biomass } \\
\hline & 1st optimization & 2nd optimization & 3rd optimization & 1st optimization & 2nd optimization & 3rd optimization & 1st optimization & 2nd optimization & 3rd optimization \\
\hline$\overline{R^{2}}$ & 0.989 & 0.95 & 0.977 & 0.901 & 0.975 & 0.96 & 0.957 & 0.95 & 0.954 \\
\hline Adjusted $R^{2}$ & 0.98 & 0.91 & 0.966 & 0.882 & 0.965 & 0.942 & 0.919 & 0.891 & 0.932 \\
\hline Predicted $R^{2}$ & 0.851 & 0.784 & 0.916 & 0.808 & 0.923 & 0.807 & 0.759 & 0.765 & 0.861 \\
\hline
\end{tabular}

interaction terms were determined. The significances of all terms in the polynomial were judged statistically according to their $p$-values.

\section{Results and discussion}

\subsection{Optimization using pure cultures}

Optimization studies using pure strains of Lb 77 and St 95/2 were performed as described in Section 2.8. The experimental runs with response variables ( $\beta$-galactosidase activity, lactic acid and biomass) are presented in Tables 1 and 2 . The results of ANOVA for all three responses show that the individual models were highly significant for each experimental design (data not shown). The $R$ square values are given in Table 4 for $\beta$-galactosidase activity, lactic acid and biomass, respectively, indicating a good agreement between experimental and predicted values. The "predicted $R^{2}$ " was in agreements with "Adjusted $R^{2}$ ".

According to the CCD (Table 1 ) and response surface plots (not shown) for $\mathrm{Lb} 77$, maximum $\beta$-galactosidase activity, biomass and lactic acid could be attained at higher temperatures and inoculum amounts at a skim milk concentration of $8-8.5 \%$. Therefore, the optimum conditions predicted by the software for maximum $\beta$-galactosidase activity $\left(1.36 \mathrm{U} \mathrm{mL}^{-1}\right)$, biomass $\left(9.43 \mathrm{~g} \mathrm{~L}^{-1}\right)$ and lactic acid $\left(13.06 \mathrm{~g} \mathrm{~L}^{-1}\right)$ were to use a temperature of $43^{\circ} \mathrm{C}$, at an inoculum of $2.40 \times 10^{8} \mathrm{cfu} \mathrm{mL}^{-1}$ and skim milk concentration of $8.0 \%$ (Table 5). The final $\mathrm{pH}$ of the fermentations ranged between $\mathrm{pH} 3.95$ and 4.53, depending on the growth of Lb 77 .

From the CCD carried out using St 95/2, maximum $\beta$-galactosidase activity could be attained at higher temperatures and inoculum amounts with whey and corn steep liquor (CSL) concentrations of $2.5 \%$ (Table 2 ). However, maximum lactic acid and biomass production could be obtained at higher temperatures and inoculum amounts with maximum whey and CSL concentrations of $5 \%$. Based on these, optimum conditions for maximum $\beta$-galactosidase activity $\left(2.03 \mathrm{U} \mathrm{mL}^{-1}\right)$, biomass $\left(9.07 \mathrm{~g} \mathrm{~L}^{-1}\right)$ and lactic acid $\left(22.76 \mathrm{~g} \mathrm{~L}^{-1}\right)$ production were defined as a temperature of $44^{\circ} \mathrm{C}$ with an inoculum concentration of $3.87 \%$ at whey and CSL concentrations of $5 \%$ and $4.16 \%$, respectively (Table 5 ).

Comparing the results of these optimization studies show that St $95 / 2$ produces 1.49 times more $\beta$-galactosidase and 1.74 times more lactic acid than Lb 77 at predicted optimum conditions. The final $\mathrm{pH}$ of the fermentations ranged between $\mathrm{pH} 4.79$ and 7.36, depending on the growth of St 95/2.

\subsection{Optimization using mixed cultures}

Based on the results obtained from the optimization studies described above, a third optimization study was performed to investigate the effect of the associative growth of Lb 77 and St 95/2 on the response parameters as a strategy to increase the product yields. The effects of inoculum amounts of St 95/2 and Lb 77 and media formulations were investigated on the response variables (lactic acid, biomass and $\beta$-galactosidase activity) using a CCD. Two types of media formulations Medium A ( $8 \%$ skim milk) and Medium B (5\% whey, $4 \%$ corn steep liquor, $2 \%$ potassium phosphate and $2 \%$ peptone), obtained from the previous optimization studies were used. It is important to note that the composition of corn steep liquor can vary depending on the source and the process; however, in this study it was obtained from a reliable source with a certain standard (Section 2.2). Therefore, this issue was not of a concern, but could be one in large-scale productions requiring special attention.

The experimental runs with response variables are presented in Table 3. The results of ANOVA for all three responses revealed that the individual models were highly significant $(p<0.0001$, data not

Table 5

Experimental and predicted values ${ }^{\mathrm{a}}$ for $\beta$-galactosidase activity, lactic acid and biomass at optimum conditions.

\begin{tabular}{|c|c|c|c|c|c|}
\hline \multicolumn{6}{|c|}{ (a) Validation experiments for first optimization } \\
\hline Running order & Inoculum (cfu mL ${ }^{-1}$ ) & Skim milk (\%, w/v) & Activity $\left(\mathrm{U} \mathrm{mL}^{-1}\right)$ & Lactic acid $\left(\mathrm{g} \mathrm{L}^{-1}\right)$ & Biomass $\left(\mathrm{g} \mathrm{L}^{-1}\right)$ \\
\hline$\overline{1}$ & $2.40 \times 10^{8}$ & 8 & $1.303(1.363)$ & $12.99(13.06)$ & $8.96(9.43)$ \\
\hline 2 & $2.34 \times 10^{8}$ & 8 & $1.269(1.360)$ & $12.05(12.94)$ & $9.65(9.44)$ \\
\hline 3 & $2.39 \times 10^{8}$ & 8.15 & $1.294(1.322)$ & $12.87(12.96)$ & $9.75(9.40)$ \\
\hline 4 & $2.40 \times 10^{8}$ & 8.63 & $1.332(1.370)$ & $13.07(12.87)$ & $10.12(9.45)$ \\
\hline \multicolumn{6}{|c|}{ (b) Validation experiments for second optimization } \\
\hline Running order & Inoculum $\left(\mathrm{cfu} \mathrm{mL}^{-1}\right)$ & $\operatorname{CSL}(\%, w / v)$ & Activity $\left(\mathrm{U} \mathrm{mL}^{-1}\right)$ & Lactic acid $\left(\mathrm{g} \mathrm{L}^{-1}\right)$ & Biomass $\left(\mathrm{g} \mathrm{L}^{-1}\right)$ \\
\hline$\overline{1}$ & $2.71 \times 10^{8}$ & 4.16 & $1.986(2.027)$ & $20.85(22.76)$ & $9.76(9.08)$ \\
\hline 2 & $2.69 \times 10^{8}$ & 4.07 & $2.015(2.032)$ & $21.55(22.77)$ & $10.15(9.06)$ \\
\hline 3 & $2.76 \times 10^{8}$ & 4.34 & $1.992(2.043)$ & $19.98(22.76)$ & $10.28(9.04)$ \\
\hline 4 & $2.73 \times 10^{8}$ & 4.17 & $2.032(2.045)$ & $21.37(22.76)$ & $8.94(9.11)$ \\
\hline \multicolumn{6}{|c|}{ (c) Validation experiments for third optimization } \\
\hline Running order & St $95 / 2\left(\right.$ cfu mL $\left.^{-1}\right)$ & Lb $77\left(\right.$ cfu mL $\left.^{-1}\right)$ & Activity $\left(\mathrm{UmL}^{-1}\right)$ & Lactic acid $\left(\mathrm{g} \mathrm{L}^{-1}\right)$ & Biomass $\left(\mathrm{g} \mathrm{L}^{-1}\right)$ \\
\hline$\overline{1}$ & $1.66 \times 10^{8}$ & $1.62 \times 10^{8}$ & $2.162(2.144)$ & $23.85(22.52)$ & $7.38(7.09)$ \\
\hline 2 & $1.61 \times 10^{8}$ & $1.62 \times 10^{8}$ & $2.108(2.134)$ & $22.61(22.50)$ & $8.05(7.14)$ \\
\hline 3 & $1.61 \times 10^{8}$ & $1.62 \times 10^{8}$ & $2.126(2.135)$ & $22.18(22.47)$ & 7.89 (7.09) \\
\hline 4 & $1.66 \times 10^{8}$ & $1.62 \times 10^{8}$ & $2.153(2.144)$ & $23.12(22.53)$ & $8.12(7.12)$ \\
\hline
\end{tabular}

${ }^{a}$ Predicted values are shown in parenthesis. Activity: $\beta$-galactosidase activity, CSL: corn steep liquor. Temperature conditions were 43 , 44 and $43{ }^{\circ} \mathrm{C}$ for first, second and third optimization, respectively. Whey (5\%) and Medium B were used in validation experiments of second and third optimization, respectively. 
shown). The $R$-square values are presented in Table 4 . The model equations for $\beta$-galactosidase enzyme $\left(Y_{\beta \text {-gal }}\right)$, lactic acid $\left(Y_{\mathrm{L}}\right)$ and $\ln$ (biomass) $\left(Y_{\mathrm{b}}\right)$ with the coefficients in coded units of factors are given below:

$$
\begin{aligned}
Y_{\text {ß-gal }}=0.88+0.036 X_{1}+0.27 X_{2}+0.37 X_{3} \\
Y_{L}=14.17+0.39 X_{1}+3.16 X_{2}+5.21 X_{3} \\
Y_{b}=7.68+1.03 X_{1}+0.71 X_{2}-1.23 X_{3}+0.77 X_{1} X_{2}-0.25 X_{1} X_{3} \\
\quad-0.20 X_{2} X_{3}-0.77 X_{1}^{2}-0.43 X_{2}^{2}
\end{aligned}
$$

From the results, maximum $\beta$-galactosidase activity and lactic acid formation was attained in Medium B with an inoculation ratio of 1.24:1.62 (St 95/2:Lb 77). Maximum biomass, however, was obtained in Medium A, with an inoculation ratio of 1.86:1.62 (St 95/ 2:Lb 77). Finally, the optimum conditions determined suggested use of these two cultures together in a ratio of 1.66:1.62 (St 95/2:Lb 77 ) in Medium B for maximum $\beta$-galactosidase $\left(2.16 \mathrm{U} \mathrm{mL}^{-1}\right)$ and lactic acid $\left(22.52 \mathrm{~g} \mathrm{~L}^{-1}\right)$ production. Under these circumstances, maximum biomass achieved was around $7.11 \mathrm{~g} \mathrm{~L}^{-1}$. Since the optimum condition for maximum biomass production in Medium A resulted in lower enzyme activity and lactic acid formation, this condition was not considered in the validation experiments. The final $\mathrm{pH}$ of the fermentation medium ranged for Medium A and Medium B between, 4.27-4.57 and 4.92-5.21, respectively.

To validate the adequacy of the models, a total of three verification experiments that were repeated four times were carried out at the predicted optimum conditions for each optimization (Table 5). As seen from the results, there was a good correlation between the experimental and predicted values. Overall, the associative growth of these cultures provided $6.4 \%$ and $39 \%$ more $\beta$-galactosidase activity and $8.73 \%$ and $44 \%$ more lactic acid compared with the results obtained using pure St 95/2 and Lb 77 strains, respectively (these numbers are based on the average actual validation experiments conducted under the defined optimum conditions, Table 5). Furthermore, this relationship provided $20.67 \%$ and $19.31 \%$ less biomass, $19.46 \%$ and $35.71 \%$ more lactic acid and $17.13 \%$ and $29.46 \%$ more enzyme yield compared with the use of pure St 95/2 and Lb 77 strains, respectively (Table 6 ). Considering the productivities (Table 6 ), associative growth provided $8.7 \%$ and $44.44 \%$ more lactic acid, $6.4 \%$ and $39.32 \%$ more $\beta$-galactosidase enzyme than pure St $95 / 2$ and Lb 77 strains, respectively. As it is obvious from the given numbers, the effect of the associative growth was more pronounced on Lb 77 than St 95/2. At large scale, these percentages can be considered as significant enhancement. In fact, this has been proven by a two-sample $t$-test by Minitab 14 statistical software (Minitab Inc., PA, USA), which confirmed the significant improvements (data not shown).

To assess the contribution of each strain, differential media were used to enumerate their numbers in the bulk mixture. In other words, the fractions of viable cell counts of individual strains in the bulk mixture were determined. From the cell count fractions, $70-80 \%$ of strain St $95 / 2$ and $20-30 \%$ of strain Lb 77 contributed to biomass, lactic acid and $\beta$-galactosidase activity (data not shown). This was also partly confirmed by the individual and associative specific growth rates of the strains under the optimum conditions. In fact, the specific growth rates of pure Lb 77 and St 95/2 under optimized conditions (first and second optimization) were 0.44 and $0.717 \mathrm{~h}^{-1}$, respectively. However, the relationship under the third optimization condition increased the specific growth rates for both strains by $28 \%$ to $0.62 \mathrm{~h}^{-1}$ and $1.00 \mathrm{~h}^{-1}$, respectively.

The increases in the parameters discussed above could be mainly attributed to the associative growth characteristics observed among these cultures. It has been reported in a number of studies that the interaction between these two organisms could be attributed to the mechanism of stimulation of the Streptococcus through the peptides released by the lactobacilli (Amoroso and Manca de Nadra, 1990; Rajagopal and Sandine, 1990; Tamime and Robinson, 1999). It is also recognized that L. delbrueckii ssp. bulgaricus could produce more proteolytic enzymes than S. thermophilus. Hence, S. thermophilus might benefit from the stronger activity of the L. delbrueckii ssp. bulgaricus and in return produce certain compounds (such as formate) that can stimulate the growth of L. delbrueckii ssp. bulgaricus (Tamime and Robinson, 1999). All these activities may take place during the incubation period and can be reflected in the amounts of the products such as $\beta$-galactosidase, lactic acid and biomass. Although, in industrial enzyme and lactic acid productions, this could be an important strategy in increasing yields of these products, there is still a lot more work needed to unravel what exactly the promoting effects are.

\subsection{Effect of $\mathrm{pH}$ on $\beta$-galactosidase activity and lactic acid production}

To investigate the effect of $\mathrm{pH}$ control on $\beta$-galactosidase activity and lactic acid production, bioreactor studies were performed with and without $\mathrm{pH}$ control for Lb 77, St 95/2 and Lb 77 plus St 95/2 according to the results obtained from optimization studies. In the first experiments, $\mathrm{pH}$ adjustment was not considered whereas, in the second experiments, $\mathrm{pH}$ was adjusted to $6.2 \pm 0.1$ by automatic addition of $2 \mathrm{~m} \mathrm{NaOH}$. These experiments were repeated twice. Fermentation was carried out for $8 \mathrm{~h}$ and samples were taken every $2 \mathrm{~h}$ for the analysis of enzyme activity and lactic acid. The duration of $8 \mathrm{~h}$ was determined in the initial shake flask experiments to result in maximum $\beta$-galactosidase activity. Since the primary goal of this study was the optimization of $\beta$-galactosidase activity rather than lactic acid production, this time point was taken as the actual fermentation time.

As it is seen from Fig. 1a, $\beta$-galactosidase activity was reduced 1.58 times for Lb 77 strain at the constant $\mathrm{pH}, 6.2$, at the end of fermentation. Lactic acid results were also lower when compared with the results obtained at uncontrolled conditions (Fig. 1b). However, for St 95/2, $\beta$-galactosidase activity was increased by $3.37 \%$ when $\mathrm{pH}$ was controlled at 6.2 , whereas lactic acid level was reduced at this condition. When both strains were used in combination, enzyme activity and lactic acid were reduced by $3.92 \%$ and $26 \%$, respectively at a constant $\mathrm{pH}$ of 6.2 . These observations could be easily linked to the natural growth requirements of these

\begin{tabular}{|c|c|c|c|c|c|}
\hline \multirow[t]{2}{*}{ Optimization } & \multicolumn{3}{|l|}{ Yield } & \multicolumn{2}{|l|}{ Productivity } \\
\hline & $Y x / s$ & $Y \mathrm{p} 1 / \mathrm{s}$ & $Y \mathrm{p} 2 / \mathrm{s}$ & Activity $\left(\mathrm{U} \mathrm{mL}^{-1} \mathrm{~h}^{-1}\right)$ & Lactic acid $\left(\mathrm{g} \mathrm{L}^{-1} \mathrm{~h}^{-1}\right)$ \\
\hline First optimization & $0.347 \pm 0.017$ & $0.459 \pm 0.028$ & $46.97 \pm 3.18$ & $0.162 \pm 0.003$ & $1.593 \pm 0.058$ \\
\hline Second optimization & $0.353 \pm 0.022$ & $0.575 \pm 0.035$ & $55.18 \pm 2.08$ & $0.250 \pm 0.003$ & $2.617 \pm 0.088$ \\
\hline Third optimization & $0.28 \pm 0.012$ & $0.714 \pm 0.019$ & $66.59 \pm 0.59$ & $0.267 \pm 0.003$ & $2.867 \pm 0.089$ \\
\hline
\end{tabular}

Table 6

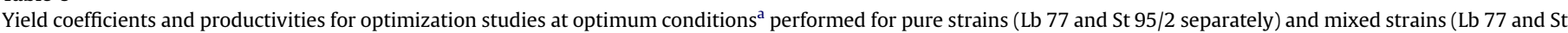
95/2).

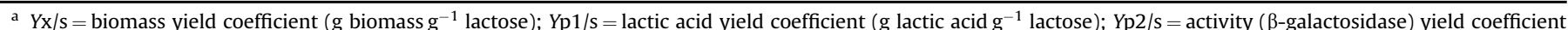
( $\mathrm{U}$ activity $\mathrm{g}^{-1}$ lactose); Values are based on the mean $\pm \mathrm{SD}$ of four validation experiments shown in Table 5. 

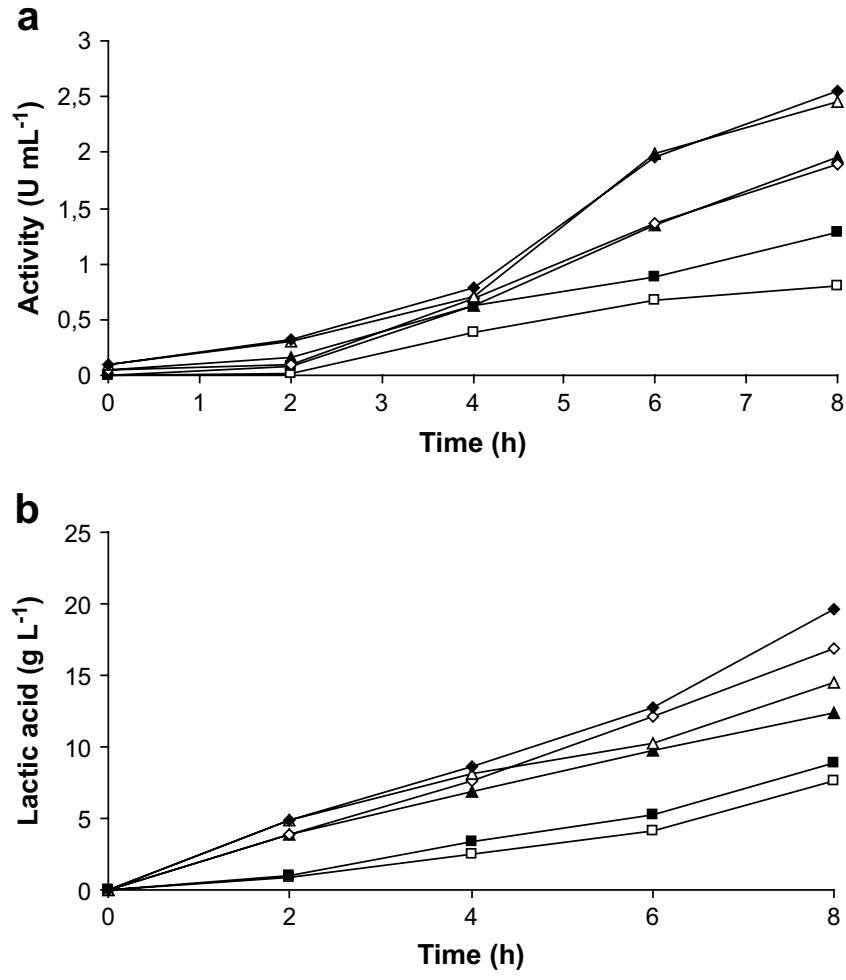

Fig. 1. Enzyme activity ( $\beta$-galactosidase activity) (a) and lactic acid production (b) under controlled $\mathrm{pH}(\mathrm{pH} \mathrm{6.2;} \square, \boldsymbol{\Delta}, \Delta)$ and uncontrolled $\mathrm{pH}(\boldsymbol{\square}, \diamond, \diamond)$ for $\mathrm{Lb} 77(\square$, $\mathbf{\square})$, St 95/2 $(\boldsymbol{\Delta}, \diamond)$ and Lb 77 and St 95/2 $(\Delta, \diamond)$ in a bioreactor. Mean standard deviations for activity and lactic acid were 0.073 and 1.52 , respectively.

individual strains. It has been reported that $S$. thermophilus grows better close to neutral $\mathrm{pH}(\mathrm{pH}$ 6.8) and is more acid-sensitive, compared with $L$. delbrueckii ssp. bulgaricus, which is more acidtolerant, growing even below pH 5.6 (Ademberg et al., 2003; Hekmat and McMahon, 1997; Kreft et al., 2001; Tamime, 2006; Vasiljevic and Jelen, 2001). Therefore, at a pH of 6.2, S. thermophilus grows more rapidly than $L$. delbrueckii ssp. bulgaricus. In fact, this is reflected in the data given above. When used in combination, however, the adverse effect of $\mathrm{pH}(\mathrm{pH}$ 6.2) on L. delbrueckii ssp. bulgaricus is partly compensated by the positive effect on $S$. thermophilus with respect to enzyme production. Another issue is that the metabolic pathways for lactic acid or production of other metabolites are strongly controlled by $\mathrm{pH}$. This is emphasized for pure as well as for mixed strains. Therefore, in the light of above discussions, it is recommended to apply an uncontrolled $\mathrm{pH}$ environment by letting the natural fermentation take over its own course.

This study clearly indicated that it is more efficient to use both strains in combination as opposed to the traditional single organism system often practiced in industrial production of lactic acid and $\beta$-galactosidase enzyme. Comparison of the current optimization results with various literature results obtained using pure strains indicated that the present results were considerably higher with respect to $\beta$-galactosidase activity (Gaudreau et al., 2005; Geciova et al., 2002; Gueimonde et al., 2002; Montanari et al., 2000). These findings were also in good correlation with a study conducted by Altıok et al. (2006) and Büyükkileci and Harsa (2004) who investigated the lactic acid formation characteristics of Lactobacillus casei NRRL B-441. Since there is no study (that we are aware of) conducted on the associative growth relation of the mixed culture with respect to $\beta$-galactosidase production, a direct comparison with the literature with this respect could not be made.

\section{Conclusion}

In this study, the optimum conditions for the production of biomass, lactic acid and $\beta$-galactosidase of new strains (St 95/2 and Lb 77) in pure as well as mixed forms were determined using response surface methodology. The associative relationship of these two strains provided higher product yields.

\section{Acknowledgements}

Financial support of Turkish Scientific and Technical Research Council (TUBITAK-TOVAG 1040270) and State Plan Organization (DPT-2005 K 120570) are gratefully acknowledged.

\section{References}

Ademberg, K., Kask, S., Laht, T.M., Paalme, T., 2003. The effect of temperature and pH on the growth of lactic acid bacteria: a pH-auxostat study. International Journal of Food Microbiology 85, 171-183.

Altıok, D., Tokatlı, F., Harsa, S., 2006. Kinetic modeling of lactic acid production from whey by Lactobacillus casei (NRRL B-441). Journal of Chemical Technology and Biotechnology 81, 1190-1197.

Amoroso, M.J., Manca de Nadra, M.C., 1990. A new mixed culture of Lactobacillus delbrueckii subsp. bulgaricus and Streptococcus salivarius subsp. thermophilus isolated from commercial yogurt. Microbiologie, Aliments, Nutrition 8, 105-113.

Beshkova, D., Simova, G., Frengova, G., Simov, Z., 1998. Production of flavour compounds by yoghurt starters. Journal of Industrial Microbiology and Biotechnology 20, 180-186.

Büyükkileci, A.O., Harsa, S., 2004. Batch production of $\mathrm{L}(+)$ lactic acid from whey by Lactobacillus casei (NRRL B-441). Journal of Chemical Technology and Biotechnology 79, 1036-1040.

Datta, R., Henry, M., 2006. Lactic acid: recent advances in products processes and technologies - a review. Journal of Chemical Technology and Biotechnology 81, 1119-1129.

El Demerdash, H.A., Oxman, J., Heller, K.J., Geis, A., 2006. Yoghurt fermentation at elevated temperatures by strains of Streptococcus thermophilus expressing a small heat-shock protein: application of a two-plasmid system for constructing food grade strains of Streptococcus thermophilus. Biotechnology Journal 1, 398-404.

Erkuş O., Celik E. S., Yavuzdurmaz, H., Okuklu, B., Harsa, S. Isolation and molecular characterization of artisanal yoghurt starter bacteria, The 20th international ICFMH symposium on food safety and food biotechnology: "Diversity and Global Impact", 2006, Bologna, Italy.

Gaudreau, H., Champagne, C.P., Jelen, P., 2005. The use of cellular extracts of Lactobacillus delbrueckii ssp. bulgaricus 11842 to stimulate growth of a probiotic Lactobacillus rhamnosus culture in milk. Enzyme and Microbial Technology 36, 83-90.

Geciova, J., Giesova, M., Jelen, P., Plockova, M., 2002. Disruption of Streptococcus thermophilus 143 culture by three mechanical methods for increased $\beta$ galactosidase activity. Milchwissenschaft 57, 509-511.

Gekas, V., Lopez-Leiva, M., 1985. Hydrolysis of lactose. Process Biochemistry 2, 2-12.

Greenberg, N.A., Mahoney, R.R., 1982. Production and characterization of $\beta$-galactosidase from Streptococcus thermophilus. Journal of Food Science 47, 1824-1828.

Gueimonde, M., Corzo, N., Vinderola, G., Reinheimer, J., De Los Reyes-Gavilan, C.G. 2002. Evolution of carbohydrate fraction in carbonated fermented milks as affected by $\beta$-galactosidase activity of starter strains. Journal of Dairy Research 69, 125-137.

Hekmat, S., McMahon, D., 1997. Manufacture and quality of iron-fortified yogurt. Journal of Dairy Science 80, 3114-3122.

Kreft, M.E., Champagne, C.P., Jelen, P., 2001. Growth of Lactobacillus dairy cultures on two different brands of MRS medium. Milchwissenschaft 56, 315-317.

Kreft, M.E., Jelen, P., 2000. Stability and activity of $\beta$-galactosidase in sonicated cultures of Lactobacillus delbrueckii ssp. bulgaricus 11842 affected by temperature and ionic environment. Journal of Food Science 65, 1364-1368.

Kristo, E., Biliaderis, C.G., Tzanetakis, N., 2003. Modelling of the reological, microbiological and acidification properties of a fermented milk product containing a probiotic strain of Lactobacillus paracasei. International Dairy Journal 13, 517-528.

Montanari, G., Zambonelli, C., Grazia, L., Benevelli, M., Chiavari, C., 2000. Release of $\beta$ galactosidase from lactobacilli. Food Technology and Biotechnology 38, 129-133.

Nancip, N., Ghoul, M., Larous, L., Nancib, A., Adimi, L., Remmal, M., et al., 1999. Use of date products in production of the thermophilic dairy starter strain Streptococcus thermophilus. Bioresource Technology 67, 291-295.

National Academy of Sciences, 1996. Food Chemicals Codex, fourth ed. National Academy Press, Washington, DC, USA, pp. 802-803.

Rajagopal, S.N., Sandine, W.E., 1990. Associative growth and proteolysis of Streptococcus thermophilus and Lactobacillus bulgaricus in skim milk. Journal of Dairy Science 73, 894-899.

Shah, N.P., 2000. Symposium: probiotic bacteria: selective enumeration and survival in dairy foods. Journal of Dairy Science 83, 894-907. 
Shah, N.P., Jelen, P., 1991. Lactase activity and properties of sonicated dairy cultures. Milchwissenschaft 46, 570-573.

Sodini, I., Lucas, A., Tissier, J.P., Corrieu, G., 2005. Physical properties and microstructure of yoghurts supplemented with milk protein hydrolysates. International Dairy Journal 15, 29-35.

Somkouti, G.A., Dominiecki, M.E., Steinberg, D.H., 1996. Sensitivity of Streptococcus thermophilus to chemical permeabilization. Current Microbiology 32,101-105.

Tamime, A.Y., 2006. Manufacture of yogurt. Fermented milks. Society of dairy technology. Blackwell Publishing, London, UK, pp. 64-65.

Tamime, A.Y., Robinson, R.K., 1999. Microbiology of Yoghurt and "Bio" Starter Cultures. Yoghurt Science and Technology, second ed. Woodhead Publishing Ltd./CRC Press, Cambridge, England/Boca Raton, FL, USA, p. 399.

Van de Casteele, S., Vanheuverzwijn, T., Ruyssen, T., Van Assche, P., Swings, J. Huys, G., 2006. Evaluation of culture media for selective enumeration of probiotic strains of lactobacilli and bifidobacteria in combination with yoghurt or cheese starters. International Dairy Journal 16, 1470-1476.

Vasiljevic, T., Jelen, P., 2001. Production of $\beta$-galactosidase for lactose hydrolysis in milk and dairy products using thermophilic lactic acid bacteria. Innovative Food Science and Emerging Technologies 2, 75-85.

Vasiljevic, T., Jelen, P., 2002. Lactose hydrolysis in milk as affected by neutralizers used for the preparation of crude $\beta$-galactosidase extracts from Lactobacillus bulgaricus 11842. Innovative Food Science and Emerging Technologies 3, 175-184.

Vasiljevic, T. Jelen, P., 2003. Drying and storage of crude $\beta$-galactosidase extracts from Lactobacillus delbrueckii ssp. bulgaricus11842. Innovative Food Science and Emerging Technologies 4, 319-329.

Yüceer, K.Y., Wilson, J.C., White, H., 2001. Formulations and processing of yogurt affect the microbial quality of carbonated yogurt. Journal of Dairy Science 84 543-550. 